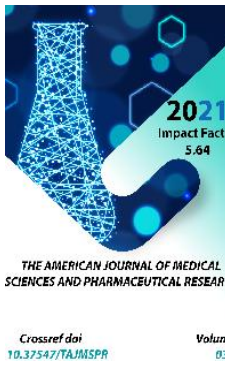

Copyright: Original content from this work may be used under the terms of the creative commons attributes 4.0 licence.

\section{Ecological And Hygienic Aspects Of Optimization Of Water Supply Of The Population}

Feruzakhon Tulkinjonovna Abduvalieva

Free Applicant For The Fergana Medical Institute Of Public Health, Uzbekistan

Feruza Lyutpillaevna Azizova

DSc, Vice-Rector For Science And Innovation Of The Tashkent Medical Academy, Scientific Director, Uzbekistan

\title{
ABSTRACT
}

The high quality of drinking water is the result of a comprehensive solution to a number of problems, the main of which are the development and implementation of modern water treatment technologies, the use of effective laboratory control mechanisms, optimization of water supply, an integral approach to assessing the quality of drinking water, the use of hygienically sound solutions in terms of water supply and sanitation.

\section{KEYWORDS}

Risk assessment, integral assessment of drinking water, safety of drinking water, ecology, hygiene.

\section{INTRODUCTION}

Optimization of drinking water supply should be carried out on the basis of a comprehensive study and hygienic assessment of the quality of natural waters. This implies a scientific substantiation of the choice of a water source from the standpoint of the hygienic reliability 
of water in terms of chemical and microbiological composition, the choice of optimal water treatment systems, water transportation to consumers, improvement of sanitary control of water quality, forecasting water reserves for the near and distant prospects, coordination of the activities of various organizations and institutions to improve the condition water resources and their rational use. A comprehensive hygienic assessment of the state of the drinking water supply of the population, taking into account the specificity of anthropogenic pollution and regional hydrochemical characteristics of water supply sources, makes it possible to make a scientifically substantiated forecast of the impact of drinking water quality on public health and substantiate measures to optimize the water supply system $[1,7]$. In addition to purifying and disinfecting water, there is a problem of maintaining its quality in the distribution network. As a rule, it worsens not only bacterially due to numerous pipe ruptures and contact with contaminated water and soil, but also due to the processes occurring in metal pipes, especially when their diameters do not correspond to the volumes of pumped water. In this case, the water is enriched with iron, sometimes the hardness increases. These processes are practically not controlled, but they are large-scale and can drastically reduce the efficiency of the entire complex water conditioning system [2]. The problem of providing the population with good-quality drinking water every year becomes more and more important due to the depletion of fresh water resources, a significant anthropogenic load on surface water bodies and underground aquifers. Availability of high-quality and safe drinking water is of paramount importance for human health, is one of his fundamental rights, determines the level of health and quality of life of the nation. Globally, more than 2 billion people do not have constant access to clean drinking water, and 844 million have to spend at least half an hour every day to get water, or do not have at all, according to the United Nations report on the state of water resources, published in 2019. access to it. Even in Europe and North America, about 57 million people do not have plumbing in their homes [21]. Today, providing the population with high-quality drinking water is one of the priority problems of state policy aimed at maintaining health and improving living conditions of the population. At present, drinking water is not so much a natural factor as a product of production; a large number of engineers, chemists, biologists, doctors, and workers are involved in its production. Natural water becomes potable only after many technological stages extraction, transportation, processing to a certain, strictly regulated by the bodies of the sanitary service quality and control over it [9].

The problem of supplying the population with high-quality drinking water is a priority in ensuring the epidemiological well-being of the population and preventing somatic and infectious diseases. An analysis of publications by domestic authors over the past decade in the field of water hygiene showed that the bulk of works are devoted to the hygienic characteristics of the quality of drinking water and the state of centralized water supply [14, 15, 23]. Conducting research in this aspect allows you to form a complete picture of the current state of the sanitary and epidemiological situation in the organization of drinking water supply.

Over the past years, the main reasons for the unsatisfactory quality of drinking water have been: anthropogenic pollution of surface and ground waters; natural factors (increased 
content of iron and manganese compounds in water), absence or inadequate condition of sanitary protection zones of water sources, use of water treatment systems that are ineffective in terms of processing highly colored source waters, deterioration of water intake structures, distribution networks, lack of qualified personnel for technological maintenance of water supply facilities , unsatisfactorily organized industrial laboratory control of drinking water quality $[5,16]$.

Water resources are one of the most important strategic resources for the economic development of countries and the biosphere as a whole. Water resources include natural and waste water [13]. Despite the rather large volume of all water sources (1.3 billion km3), the share of fresh water, the most significant for human needs, does not exceed $2-2.6 \%$. The distribution of fresh water sources is extremely uneven; There is a shortage in more than 80 countries of the equatorial part of the planet, while the countries of the temperate zone and some countries of South America (Brazil, Peru) are provided with fresh water to a much greater extent [24]. According to the UN, in 2000 more than 2 billion people suffered from water shortages, by 2015 half of the population, and in 10 years two-thirds of the world's population will face water shortages $[6,12]$.

It is known that the threat to the existence of mankind lurks in a catastrophic ecological situation. One of the most serious concerns is the lack of drinking water, its qualitative changes, and non-compliance with sanitary and hygienic requirements. In addition, in our enlightened age, a causal relationship between the quality of the water used and the state of human health has been fully revealed. It became quite obvious that the issues of providing the population with good-quality water, the creation of the necessary sanitary conditions are inseparable from the issues of health protection and require an approach from the point of view of environmental laws. The World Health Organization (WHO) estimates that $80 \%$ of all diseases on Earth are caused by polluted water or lack of basic hygiene conditions. According to this organization, more than 500 million people annually suffer from the consumption of poorquality drinking water (L.S. Skvortsov, 1996). Due to the active pollution of surface water bodies, many countries exploit underground aquifers for domestic and drinking water supply [14]. With the infiltration of atmospheric precipitation through the ground, the bulk of groundwater used for domestic drinking water supply $(60-70 \%)$ is protected from pollution. One of the main reasons for the unsatisfactory quality of groundwater is non-observance of sanitary protection zones, as well as the technological process of isolating aquifers during the drilling of artesian wells [25]. Formation of lists of indicators for assessing and monitoring the safety of drinking water remains a very difficult and responsible task while ensuring favorable conditions for the drinking water use of the population $[11,18]$.

Poor quality water is the second after poverty risk factor for the development of diseases [15]. Therefore, the most important task in the field of creating sanitary and epidemiological well-being of the population in the Republic of Uzbekistan is to provide it with high-quality drinking water, epidemiologically safe (in terms of microbiological composition) and harmless in chemical composition. At the same time, drinking water should also be useful, since it largely determines the body's watersalt metabolism (up to $10 \%$ of minerals occur 
with drinking water). Of particular importance is fluorides, since these substances come only with water (in food they are contained in a poorly digestible form) [15]. The State Standard of Uzbekistan "Drinking water. Hygienic Requirements and Quality Control "presents the main indicators of water quality: organoleptic, sanitary-chemical and microbiological. It also provides for the study of the content of a number of chemicals found in natural waters or added to water during its preparation. The quality of tap water must comply with modern regulatory requirements not only at the outlet from water treatment plants, but also in the distribution network of the city, that is, at the consumer [22].

Natural and anthropogenic pollution of water sources, the process of water treatment and operation of water supply systems, deterioration of water supply networks, a shortage of good-quality drinking water, the development of new industries, the continuation of legally prohibited discharges of contaminated wastewater are the main factors that have a negative impact on the quality of drinking water supply, which is aggravated by the emergence of new challenges and threats $[4,17]$. One of the determining factors affecting the quality of drinking water is a high level of pollution of water supply sources, leading to the need for large-scale water treatment [20].

The problem of drinking water supply is extremely urgent, and the provision of the population with good-quality water is one of the main components of the quality of life of the population [3, 19, 26, 27]. It is underground waters that are traditionally considered the best sources of drinking water supply for the population as the most protected from anthropogenic pollution. However, the absence of the impact of technogenic factors does not solve the problem of conformity of groundwater quality to hygienic requirements, since the formation of groundwater is closely related to natural factors - local hydrogeological features of aquifers. A significant influence on the chemical composition of groundwater is exerted by the nature of the rocks of the aquifers, upon contact with which they are enriched with the chemical elements that make up these rocks $[8,10]$. The use of underground water sources for centralized water supply has a number of significant hygienic advantages over the use of surface sources. The most important of them are the protection of water from external pollution, safety in the epidemiological respect, the constancy of the quality and flow rate of water. Usually groundwater does not need clarification, discoloration and disinfection. Among the disadvantages of using groundwater is the need, as a rule, for the device of several water intakes due to the limited flow rate of individual structures, which complicates the operation and organization of sanitary control [9].

Providing the population with drinking water of high quality in terms of organoleptic properties, harmless to health in terms of chemical, microbiological and radiological indicators that meet the requirements of GOST, remains an urgent hygienic problem in the Republic of Uzbekistan.

Thus, the problem of supplying the population with high-quality water remains relevant and its solution requires coordinated work of various enterprises, institutions, organizations, which is really feasible provided that a set of priority and long-term research sanitary and hygienic, industrial, socio-economic, organizational and economic measures is 
developed. to improve the state of water resources with a justification of the types, volumes of work and the sequence of their implementation.

\section{REFERENCE}

1. Berezin, I.I. Regional features of the chemical composition of drinking water for household and drinking water supply in the city of Samara // Bulletin of the Samara Scientific Center of the Russian Academy of Sciences. - 2011. - T. 13, No. 1 (8). - P. 1837-1840.

2. Bobun, I.I. The state of water supply sources in the Arkhangelsk region // Proceedings of the Arkhangelsk Center of the Russian Geographical Society, collection of scientific articles. Arkhangelsk, 2013. - P. 284-289.

3. Burlibaev M.Zh., Neronova T.I., Saidov I.I., Mirkhashimov I.Kh., Kaidarova R.K. and others. Prospects for the harmonization of water quality standards and norms in the countries of Central Asia and the Water Framework Directive of the European Union. Almaty: PA "OST-XXI century", 2010. $240 \mathrm{p}$.

4. Valeullina N.N., Beketov A.L., Nikiforova E.V. and other Assessment of the health risk of the population of the city of Chelyabinsk from chemical pollution of drinking water. Materials of the VIII AllRussian Scientific and Practical Conference with International Participation "Topical Issues of Risk Analysis in Ensuring the Sanitary and Epidemiological Well-Being of the Population and Protection of Consumer Rights" / Ed. prof. Popovoy A.Yu., acad. RAS Zaitseva N.V. Perm, 2018, pp. 19-21.

5. Vorobieva L.V. et al. Regional features of hygienic assessment of biological pollution of surface waters // Hygiene and sanitation. 2011. No. 1. P. 34-37.

6. Danilov-Danilyan, V.I. Environmental challenge and sustainable development. Textbook. - M.: Progress-Tradition, 2000. $416 \mathrm{p}$.

7. Egoricheva S.D., O.A. Rodyukova, A.V. Avchinnikov Hygienic assessment of the state of drinking water supply for the population of the Smolensk region // Public health and environment. - 2016. No. 6 (267). - P. 16-19.

8. Zektser I.S. Groundwater runoff and fresh water resources. Current state and prospects. M.: Scientific world; 2012.

9. Ignatieva LP, MO Potapova Hygiene of drinking water supply Textbook. Irkutsk, ISMU 2015. -99 p.

10. Krainov S.R., Ryzhenko B.N., Shvets V.M. Geochemistry of groundwater. Theoretical, applied and environmental aspects. 2nd ed. M.: TsentrLitNefteGaz; 2012.

11. Krasovsky, G.N. Hygienic rationale for optimizing the integral assessment of drinking water by the water quality index // Hygiene and Sanitation. - 2015. - T. 94, No. 5. - P. 5-10.

12. Krasnogorskaya, N.N. Assessment of the geoecological hazard of water bodies within the city of Ufa // Bulletin of MGSU. 2013. -No. 11. - P. 161-166.

13. Markin, V.N. Integrated use of resources and protection of water bodies. Tutorial. Part 1. - Moscow: MGUP, 2015. - 312 p.

14. Mirkina, E.N. Water supply of the Saratov region // Materials of the international scientific-practical conference "Results of scientific research" - Ufa: AETERNA, 2016. - pp. 210-212.

15. Motovilova N.Yu., Volkotrub L.P. Hygienic assessment of drinking water in the city of 
Tomsk. Siberian Medical Journal. 2012; 27 (3): 151-7.

16. Review of the state and environmental protection of the Novgorod region in 2012. Veliky Novgorod: Committee for Environmental Protection and Natural Resources of the Novgorod Region, 2013. P. 21-59.

17. Popova A.Yu. Strategic priorities of the Russian Federation in the field of ecology from the standpoint of preserving the health of the population // Health of the population and the environment. 2014. No. 2 (251). P. 4-7.

18. Rakhmanin, Yu.A. Modern hygienic problems of centralized provision of the population with drinking water and ways to solve them // Environmental problems of our time: identification and prevention of the adverse impact of anthropogenically determined factors and climatic changes on the environment and public health. Materials of the Intern. Forum of the Scientific Council of the Russian Federation on Human Ecology and Environmental Hygiene. - Moscow, 2017. - pp. 7-12.

19. Rakhmanin Yu.A., Krasovsky G.N., Egorova N.A. 100 years of legislative regulation of drinking water quality. Retrospective, current status and prospects. Hygiene and sanitation. 2014; 93 (2): 5-18.

20. Rakhmanin Yu.A. 1, Meltser A.V.2, Kiselev A.V.2, Erastova N.V. Hygienic substantiation of management decisions using an integral assessment of drinking water in terms of chemical safety and epidemiological safety // Hygiene and Sanitation 201796 (4). P.302-305.

21. Guidelines for ensuring the quality of drinking water. - 4th ed. [Electronic resource] // World Health Organization. -
2017. - 628 p. - (date of access: 18.06.2019).

22. Senina N.D., Bocharova T.V., Spiryakova T.A. The state of drinking water supply and the quality of drinking water in Moscow, problems and solutions. Materials of the $X$ Congress of Hygienists and Sanitary Physicians. - M., 2007. P. 447-451.

23. Turbinsky V.V. Assessment of the health risk of drinking water with a high content of humic substances // Public health and environment. - 2015. - No. 2 (263). - P. 2528.

24. Kholova, A.R. Monitoring and assessment of the impact of technogenic organic pollutants on the integral indicator of the chemical safety of drinking water in Ufa: dis. ... Cand. chem. Sciences: 03.02.08, 02.00.02. - Ufa, 2017. - 149 p.

25. Sherenkov, I.A. Analysis of problems of operation of drinking water supply systems from underground sources /I Bulletin of the Samara Scientific Center of the Russian Academy of Sciences. - 2009. T11- No. 1. - P. 350-352.

26. Bain RE, Gundry SW, Wright JA, Yang H, Pedley S, Bartram JK. Accounting for water quality in monitoring access to safe drinking-water as part of the Millennium Development Goals: lessons from five countries. Bulletin of the World Health Organization. 2012; 90 (3): 228-235A.

27. Guidelines for drinking-water quality: fourth edition incorporating the first addendum. Geneva: World Health Organization; 2017. 